\title{
Historical perspectives of The American Association for Thoracic Surgery: D. Craig Miller (1946-)
}

\author{
Abe DeAnda, Jr, MD, ${ }^{\mathrm{a}}$ and Marc R. Moon, $\mathrm{MD}^{\mathrm{b}}$
}

\section{"Only he who attempts the ridiculous may achieve the impossible."

$$
\text { —Miguel de Unamuno (1864-1936) }{ }^{1}
$$

David Craig Miller (Figure 1), 88th president of The American Association for Thoracic Surgery (AATS), was born on December 3, 1946, in San Francisco to Dr Charles "Bebe" and Helen Miller. After spending the first 9 years of his life in the San Francisco Peninsula, Miller's father grew weary of the crowds and moved the family to the mountains in northern California. Miller grew up in Redding, where he spent his formative years alternating between being a bibliophile, a high school athlete, and a farmhand on his father's ranch (Figure 2). Miller broke a lot of bones as a youngster on the rodeo circuit, a sport that epitomized the adventurous spirit that would dominate his future career path and extracurricular interests as an adult.

Miller attended Dartmouth College for 3 years and entered Stanford University School of Medicine in 1968 without an undergraduate degree (as was then permissible). Subsequently his bachelors degree in basic medical science was awarded by Stanford in 1969 and his MD in 1972. Under the spell of Dr Norman Shumway (67th AATS president), Miller decided to pursue a career in cardiovascular surgery. Miller also credits Drs Randall Griepp and Lawrence Cohn (79th AATS president) with guiding his early career. Dr Griepp was a young faculty member at Stanford who helped convince Dr Shumway to give Miller a chance, and Dr Cohn was Shumway's chief resident during Miller's formative medical school years. Miller then spent 4 years in general surgical training, 1 year in peripheral vascular surgery, and 18 months in adult cardiothoracic surgery. In January of 1978, he joined the faculty of Stanford. Sometime along the way, Miller dropped his first given name, becoming "Craig" or, to his colleagues and residents, "DCM."

\footnotetext{
From the Department of Cardiothoracic Surgery, ${ }^{a}$ New York University-Langone Medical Center, New York, NY; and the Division of Cardiothoracic Surgery, ${ }^{b}$ Washington University School of Medicine, St Louis, Mo.

Disclosures: Authors have nothing to disclose with regard to commercial support. Received for publication April 4, 2014; revisions received April 15, 2014; accepted for publication April 17, 2014; available ahead of print May 22, 2014.

Address for reprints: Abe DeAnda, Jr, MD, Department of Cardiothoracic Surgery,

NYU-Langone Medical Center, 530 First Ave, Suite 9V, New York, NY 10016

(E-mail: abe.deanda@nyumc.org).

J Thorac Cardiovasc Surg 2014;148:1785-7

$0022-5223 / \$ 36.00$

Copyright (c) 2014 by The American Association for Thoracic Surgery

http://dx.doi.org/10.1016/j.jtcvs.2014.04.034
}

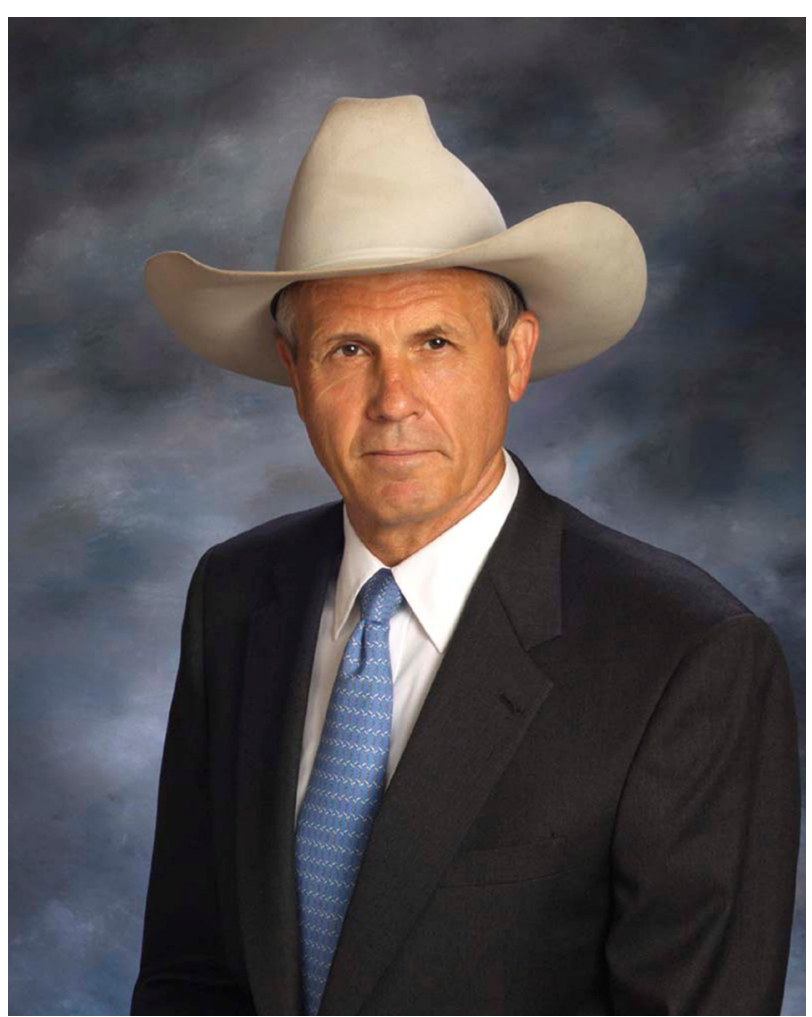

FIGURE 1. D. Craig Miller, MD.

As a young faculty member with training in both vascular and cardiac surgery, Miller developed an interest and expertise in aortic surgery, in part influenced by Dr Griepp. Miller's clinical proficiency spanned from the aortic root to the aortic bifurcation, and occasionally beyond. In 1983, Miller became the principal investigator of National Institutes of Health grant R01 HL 29589, "Ventricular Dynamics from Surgically Inserted Markers," a grant that was continuously funded under his direction for the next 26 years. Miller's laboratory, affectionately referred to as the "Miller Lab" both at Stanford and throughout the country, used miniature radiopaque, implantable myocardial markers to investigate the subtleties of biventricular function and mitral valve physiology. Miller was the recipient of numerous other R01 grants and VA Merit Review grants through the years, a remarkable feat for the often busiest surgeon at Stanford for nearly 4 decades. Miller's curriculum vitae currently lists 562 articles in peer-reviewed journals, a number that is sure to climb as he continues his 


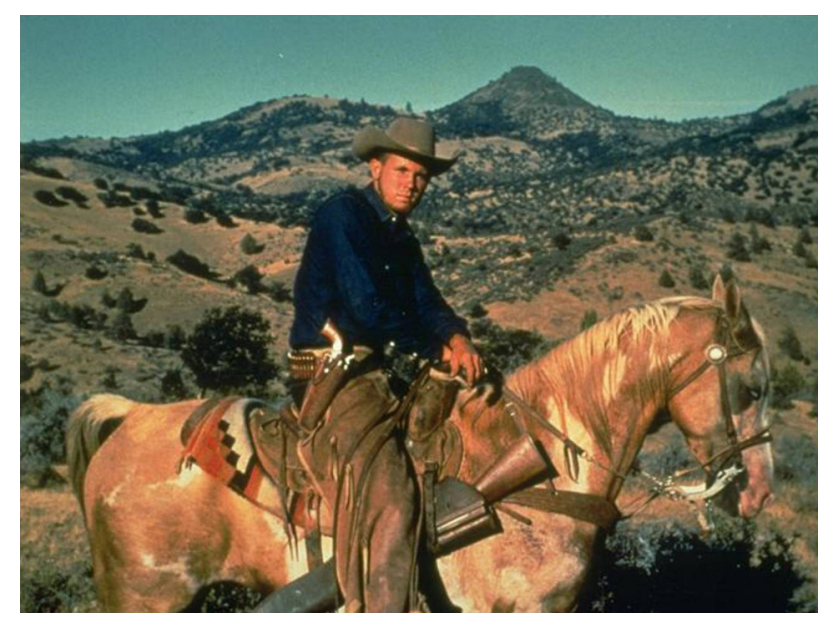

FIGURE 2. Miller on horseback, tending the ranch.

illustrious career at Stanford under his fourth "regime change." Miller is one of only a handful of AATS past presidents who was never chief of a division or department:

I've shied away from leadership roles because it would detract from what I think I do best and that is teach, do laboratory research, and operate. In today's world you can't be an effective and successful chief of cardiovascular surgery or chairman of cardiovascular surgery unless you spend an immense amount of time in this administrative political dog battle and that's just not for me.*

Miller's reputation as an aortic and valve surgeon was enhanced by his skill as a teacher both in and out of the operating room. Eschewing conventional practice in complex aortic reconstruction, he remained on the assistant's side of the operating table, calmly and deliberatively instructing his residents and thereby providing true experience and confidence in his trainees. Miller insisted that his trainees consider all aspects of the procedure, and many a resident, after making an error in technique or approach, can still hear the gentle rebuke, "Close your eyes, count to 10 , and think!" This admonition, however, was not necessarily reserved exclusively for his trainees; it was often self-directed. Dr Tirone David (85th AATS president) recalls an indelible comment that Miller made from the podium nearly 15 years ago. "I am an eternal student and my education will never be completed," professed Miller. Dr David remains impressed with Miller's continual quest for knowledge acquisition and self-improvement (Tirone E. David, personal communication, 2012).

On May 12, 2008, Miller delivered the presidential address at the 88th annual meeting of the AATS, in San

\footnotetext{
* All Dr Miller's quotations are drawn from his 2008 AATS presidential address or his AATS past president interview (January 2012, pending publication at the AATS Centennial) unless otherwise noted.
}

Diego, California. The title of his talk was "Anti-Memoirs of Rocinante," a tribute to the philosophical writings of Søren Kierkegaard, André Malraux, and Miguel de Cervantes Saavedra. The main theme of his address was personal responsibility and change. He quoted Dr C. Walton Lillehei, "the importance of comforting the sick and dying, is, indeed, a doctor's moral obligation," and then laid down the challenge in the form of a rhetorical question, "Why is medicine no longer a noble profession?" Specific illustrations of the current health care crisis were provided, including the relationship of costs and utilization as demonstrated by Roemer's Law; medical "demand" expands to consume the supply of resources, a case of supplysensitive care and supply-driven demand.

The audience was challenged to consider their roles in this system, with the expenditure of resources concentrating at the end of a patient's life. Possible solutions presented included regionalization of expertise and institution of best practices, something seen in countries other than the United States. Miller admitted that these proposals seemed at odds with his previous beliefs, stating, "I started off as a very far-right wing Goldwater Republican or even John Birch Society sort. When I leave this world I may be just like Eloesser and Holman and Shumway and leave this world as a socialist ... it's called maturity."'

Acknowledging the role that surgeon-educators play in shaping not just the skills but also the minds of future generations, Miller then described what many consider the finest accomplishment of his presidency. Perhaps by virtue of his experience on his father's ranch, Miller was able to herd the discordant minds and agendas of various societies and organizations into the creation of the Joint Council on Thoracic Surgery Education, with the memorandum of understanding signed only the day before his presidential address. The goal was to homogenize the educational

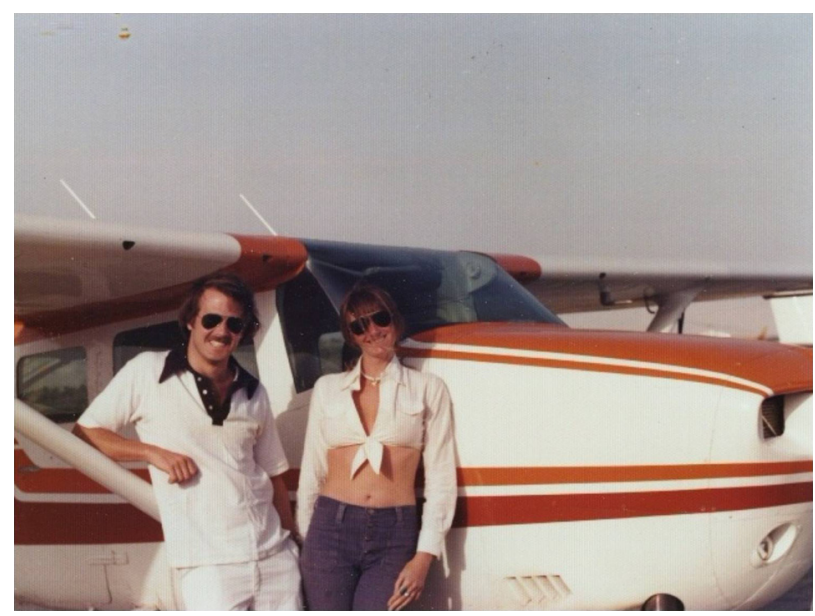

FIGURE 3. Miller and his wife, Sandy Laws, in the late 1970s on a flight to Baja, California. 


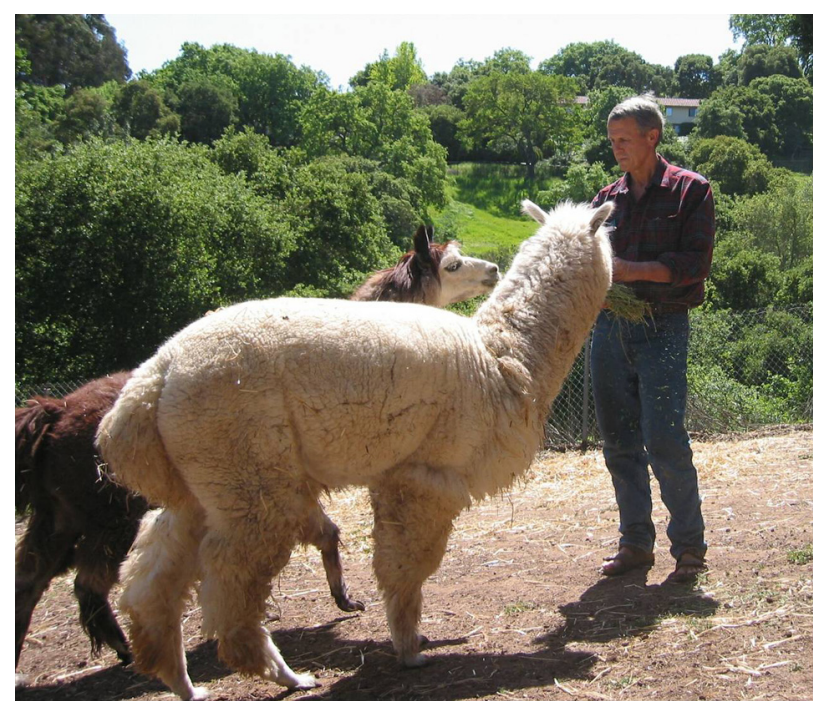

FIGURE 4. Craig helping feed Sandy's alpacas in their backyard.

experience of residents while at the same time exploring new and innovative approaches to surgical training, including the emergence of the novel integrated 6-year program, the ongoing success of which lends credence to his vision.

Since 1998, Miller has been the Thelma and Henry Doelger Professor of Cardiovascular Surgery at Stanford. In addition to the AATS presidency, Miller served as president of the Western Thoracic Surgical Society as well as holding leadership positions in the American Heart Association and on numerous editorial boards. Fluent in Spanish, he was the president of the Sociedad de Cardiocirujanos (Spain) in 1987 and 1988. Outside the hospital, Miller somehow found time to serve as a lieutenant in the United States Naval Reserve for 13 years and has remained an avid hunter, accomplished water-skier, amateur radio operator (call sign WA6OXK), and, with his wife Sandy Laws, Cessna pilot (Figure 3) and breeder of alpacas (Figure 4).

Craig and Sandy have been married for more than 30 years. Sandy had her own independent career, in which she worked 12-hour days and was on call nights and weekends for computer systems failures. Miller noted, "Sandy was dedicated to her career, but perhaps not quite as pathologically as I was to mine." Although Craig and Sandy never had any biologic children, there is an extended family of former trainees who consider Miller the father of their surgical career, in large part because of his passion for teaching and never-ending thirst to "make things better." Despite a monumental career thus far spanning his first 67

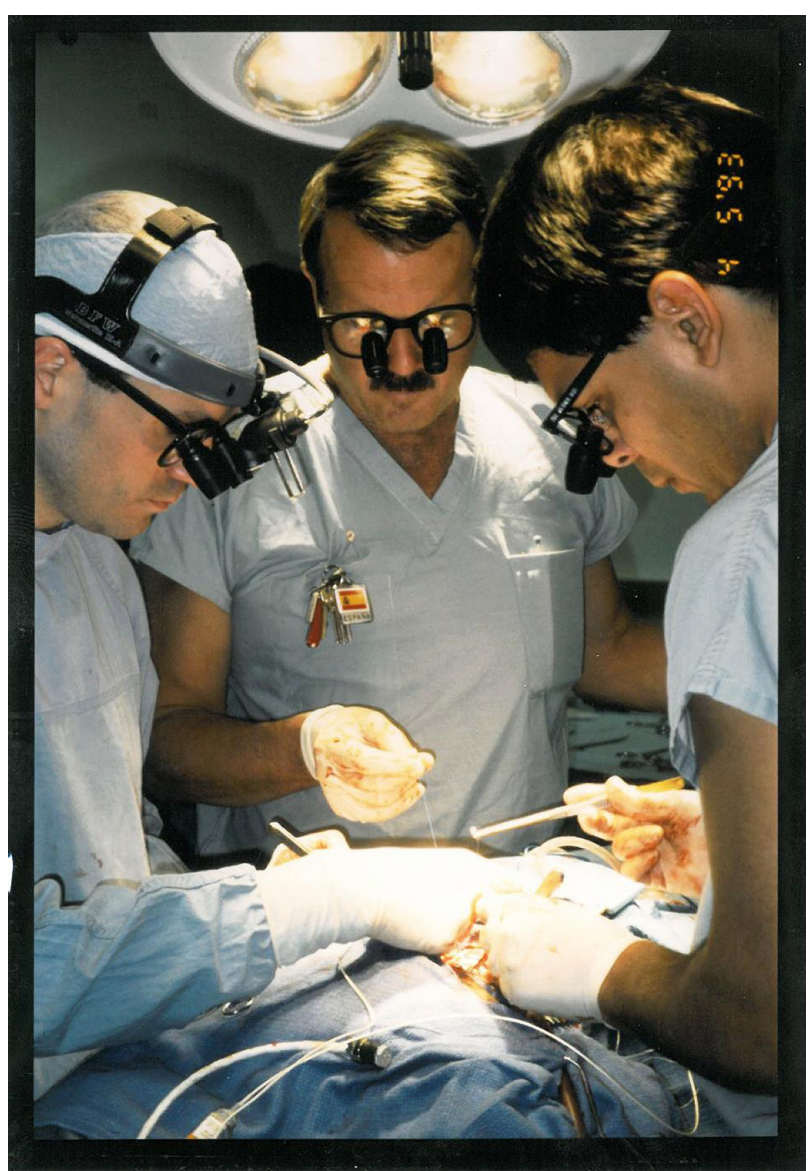

FIGURE 5. Miller in the laboratory in 1993 with the authors of this perspective (left, Marc R. Moon; right, Abe DeAnda, Jr), reminding them to "Close your eyes, count to 10 , and think!"

years, Miller admittedly is not done advancing the field and continues to look to the future:

Today is the last day of the rest of your life, and if you live it as if it's the last day of the rest of your life, and Lord knows none of us know how many days we have left on this planet, you will live life to the fullest. You can't be afraid to fail, and you have to challenge dogma or we're not going to get better.

Powerful words of encouragement, indeed, from one of the few consummate triple threats in cardiothoracic surgery of our generation (Figure 5).

\section{Reference}

1. de Unamuno M. The Life of Don Quixote and Sancho. New York, NY: Alfred A. Knopf; 1927. 